\title{
Realist Review of Literature on Catering for Different Instructional Needs with Preteaching and Extended Instruction
}

\author{
Wouter Smets ${ }^{1, *(1)}$ and Katrien Struyven ${ }^{2,3}$ \\ 1 Department of Tacher Education, Karel de Grote University College, 2018 Antwerp, Belgium \\ 2 Department of Psychology and Educational Sciences, Vrije Universiteit Brussel, 2, 1050 Ixelles, Belgium; \\ Katrien.Struyven@vub.Be \\ 3 Department of educational studies, University of Hasselt, 3500 Hasselt, Belgium; \\ katrien.struyven@uhasselt.be \\ * Correspondence: wouter.smets@kdg.Be; Tel.: +32-485-312-967
}

Received: 8 July 2018; Accepted: 23 July 2018; Published: 3 August 2018

check for updates

\begin{abstract}
This literature review focuses on achieving educational equity through catering for differences in students' instructional needs. In heterogeneous classes the need for tailored direct teacher instruction is dependent upon students' instructional needs. Realist review methodology is used to study how instructional strategies can add to catering for students' different needs. The focus lies on two proactive strategies in which teachers cater for these differences, namely preteaching and extended instruction. The aim of this realist review is to verify how preteaching and extended instruction may contribute to catering for students' different instructional needs. It is noticed that the complexity of differentiated teaching is not always reflected in studies on preteaching and extended instruction. The focus of many studies lies in measuring learning progress in a linear and fixed way for a selected group of students which is not aligned with theory on differentiated instruction which suggests cyclical teaching processes. To respond to students' needs ongoing monitoring of cognitive and affective indicators of learning is needed. Implications for theory and practice are discussed.
\end{abstract}

Keywords: differentiated instruction; preteaching; extended instruction; realist review; complexity

\section{Introduction}

\subsection{To Cater for Different Instructional Needs}

Many scholars agree on the important role of direct instruction in a learning process [1]. Direct instruction in "which the teacher provides strong instructional support, scaffolding, and feedback" [2] (p. 46), may be seen as pivotal to fostering students' learning [3,4]. However, as heterogeneity in classes increases, the challenge of tailoring instruction to students' instructional needs becomes increasingly difficult. In a multicultural context students might, for instance, need additional or tailored direct instruction based on their (lack of) prior knowledge, (foreign) linguistic background, or cultural learners' profiles [5]. Adapting instructional design to heterogeneity in classes is, therefore, a major challenge when promoting educational equity, particularly in multicultural settings. Moreover, it is even thought to be one of the main challenges of the educational sciences [6].

Although no clear description exists of the idea of students' 'instructional needs', many studies point to its relevance for both theory and practice. To adapt instructional design to different needs of students is an important factor that influences the effectiveness of learning processes [7]. Cognitive differences are not the only ones on which differentiated teaching is based. Cordova, Sinatra, Jones, Taasoobshirazi, and Lombardi argue that beside prior knowledge differences in self-efficacy 
and interest must also be used to determine the learning profile of students [8]. Hence, differences in students' instructional needs may also be based on these differences. Student-centered instruction is said to be one of the main characteristics of culturally responsive teaching [9]. It has been repeatedly found that students in multicultural settings benefit from adaptive teaching practices in which teachers intend to consider these differences [10,11].

Tomlinson proposes a model for differentiated instruction which she refers to as, "the teachers' response to differences in readiness, interest and learning profile between students" [12] (p. 15). Likewise, Hall considers not only readiness and prior knowledge, but also interest and learning profile as constitutive elements for instructional design to adapt to student heterogeneity [13]. Depending on different proficiency levels of the language in which teaching happens, some students need more, less or tailored instruction [14]. Migratory school biographies of students may also explain different readiness levels [15]. Moreover, the cultural background of students may relate to students' interest or disinterest in particular topics or to their learning profile [16]. It is important in heterogeneous multicultural settings to be aware of students' different readiness levels, interests and learning profiles, and hence of their different instructional needs.

Drawing upon Tomlinson's model for differentiated instruction, students' instructional needs can be seen as depending on students' readiness level, interest or learning profile [12]. Teachers are challenged to find a didactical answer to this in class. Assessment can provide the necessary information on which to base instructional design. First, this includes pre-assessment of students' characteristics. In addition to this, formative assessment is an essential element in assessing further development of students' different instructional needs [17]. Hall, therefore, proposes a cyclical view on differentiated instruction such as that proposed in Figure 1 [13]. The challenge to tailor instruction to students' instructional needs is central to this article. A realist review was made to scrutinize how two strategies of direct instruction, preteaching and extended instruction, may add to catering for students' different instructional needs.

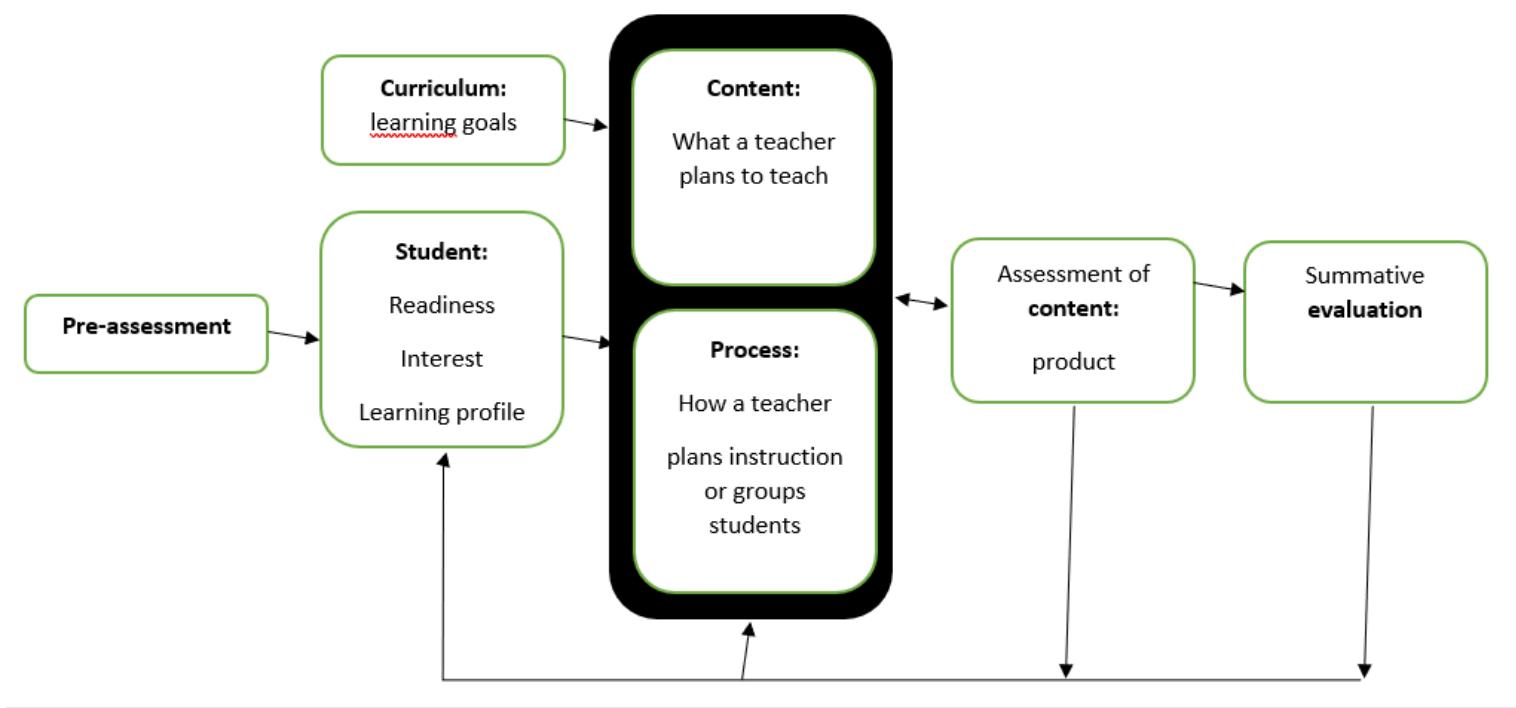

Figure 1. The cyclical process of differentiated instruction (Hall), adapted from Oaksford and Jones $[13,18]$.

\subsection{Preteaching and Extended Instruction}

A teacher's response to heterogeneity in a class may consist of a plethora of different strategies. Learning contracts, station teaching or collaborative learning strategies are, among other methods, used for differentiated teaching [19]. Another idea is to provide tailored direct teacher instruction [20]. All these strategies are used in multicultural educational settings to enable teachers to provide equitable education for all [21,22]. Students are provided with opportunities based on their supposed 
learning needs. In this literature review, focus lies on this last option, which is characterized by interaction between students and teachers. Two forms of tailored direct instruction were studied, namely preteaching and extended instruction. Both strategies were chosen based on Bosker, who calls for a proactive approach in catering for students' different learning needs and on Kirschner, Sweller, and Clark, who appeal for strongly structured learning environments [23,24].

In scholarly studies, the concepts of preteaching and extended instruction are not universally defined. The use is not necessarily limited to studies with regarding differentiated teaching; in many cases, both strategies are applied as a whole-classroom approach. In the case of preteaching, for instance, the strategy is sometimes used as an orientation activity when a teacher introduces a new topic. To avoid confusion, we first define both concepts for their use in response to different instructional needs among students.

Preteaching (PT) is an instructional strategy in which students are prepared for new content by offering them instruction prior to a moment of whole-class instruction or practice. Reactivating it prompts necessary prior knowledge or schemes. Hence, PT is closely related to advance organizers [25]. These are usually described as frames or schemes that are offered to structure thoughts in preparation for learning tasks [26]. PT may take the form of an advance organizer, but it may also be limited to the instruction of vocabulary or ideas. If such instruction is provided for a whole class, it may be an interesting teaching strategy, yet we do not regard it as catering for students' different instructional needs. As a strategy for differentiated instruction, preteaching responds to differences between students (see Figure 1, pre-assessment). The target is to assure that all students are sufficiently prepared for a particular whole-class instruction or assignment. This may, for instance, be used for students who have missed a class or a topic that is seen as a constitutive element to be able address subsequent topics. Moreover, in a multicultural classroom, recently migrated children could not have the required prior knowledge to be able to successfully attend a lesson sequence. Children of diverse linguistic backgrounds may need additional instruction on technical vocabulary. Preteaching could help then to narrow this gap in order to more adequately prompt students' zone of proximal development [27].

Extended instruction (EI) is instruction that is provided for students in addition to an initial instruction. It aims to support students in reaching their targeted learning goals. The difference with basic instruction lies in the fact that students who do not need it are either set other assignments or they receive other more tailored instruction later. Hence, teachers may choose to rehearse a particular topic or to repeat it with other examples when faster students are working ahead. A teacher could also choose extended tailor-made instruction for high-ability students while slower students work on a basic exercise or assignment. By doing this, the strategy responds proactively to differences in students' instructional needs. EI may be used in a variety of ways to more appropriately cater for students' diverse instructional needs. In multilingual contexts, students' need for more or less explicit teacher-centered instruction may be strongly divergent. Therefore, it may be useful to provide additional direct instruction for students for whom a standardized amount of whole-class instruction is not sufficient to enable individual work on assignments. Moreover, EI could also be used to foster the development of students' diverse interests. By providing additional instruction based on students' interests, teachers have the chance to more carefully respond to students' cultural backgrounds and learning needs $[28,29]$.

\subsection{The Complexity of Catering for Students' Instructional Needs}

Thoughtful considerations must be made when applying the principles of differentiated instruction. Sometimes tailored strategies seem to yield unintended or unexpected results [30]. This may be because differentiated instruction considers many of interdependent factors such as those presented in the cyclical framework for differentiated teaching (see Figure 1). Each of these factors mediates the eventual learning outcomes. By acknowledging that differences between students may be larger than simply cognitive ones, the number of variables turns out to be high. Hence, teachers 
face a difficult task when attempting to take into account this complexity. The following example illustrates the complexity of the discussion.

Homogeneous ability-grouping is an often criticized strategy [31]. When students are organized in ability groups, this is said to undermine students' self-efficacy beliefs and to negatively influence teachers' expectations [32], especially when this is done across classes. However, no consensus exists when students are put in temporary homogeneous ability groups [33-35]. Regarding homogeneous within-class grouping, different learning effects are described for high- and low-ability students. In addition to this, differentiated effects are described on students' self-efficacy. Hence, it is unclear to what extent it is fruitful to propose preteaching or extended instruction in homogeneous ability groups. Teachers who want to provide instruction that caters for students' instructional needs are bound to take all these complex considerations into account.

The intention is to verify to what extent both strategies may contribute to catering for different instructional needs in a class. Two research questions are addressed: (1) how can preteaching and extended instruction be used as differentiated instructional strategies; and (2), which differentiated effects of both strategies are described? Empirical scholarly studies are used to answer these questions. To answer the first research question, we regard strategies as differentiated when they target catering for different instructional needs within a class. To answer the second question, effects are regarded as differential when a similar approach yields different effects within a group of students.

\section{Method}

To acknowledge the complexity of teaching in a differentiated class, a realist review methodology was chosen [36]. This section is based on the criteria for realist review studies of Pawson, Greenhalgh, Harvey, and Walshe: (1) definition of scope; (2) search for and appraisal of evidence; (3) extraction and synthesis of findings; and (4) drawing conclusions [37].

Realist review procedures share several similarities with classic systematic reviews. An essential difference, however, is that it is acknowledged that interventions are never implemented in the same context; hence, results are always context-dependent. As a result of this, the ambition is not to provide a list of recommendations, or a clear answer to a 'what-works-question'; realist reviews never yield generalist statements, rather conclusions are context-dependent. Through the analysis and synthesis of recent research findings, we aim to give insight onto the complexity of teaching in a differentiated classroom, in order to foster teachers' research-informed professional decision making [38,39].

\subsection{Definition of Scope}

Based on the research questions described in the first section, this realist review of literature focused on two instructional strategies with which teachers respond to differences in instructional needs in a class. First, it was verified how preteaching and extended instruction are used as strategies for differentiated instruction. Second, it was analyzed which differentiated effects of both strategies are described.

\subsection{Search for Evidence}

Broad inclusion- and exclusion-criteria were adopted to assure that the eventual synthesis was based on a broad spectrum of evidence. Figure 2 provides an overview of the search strategy. 


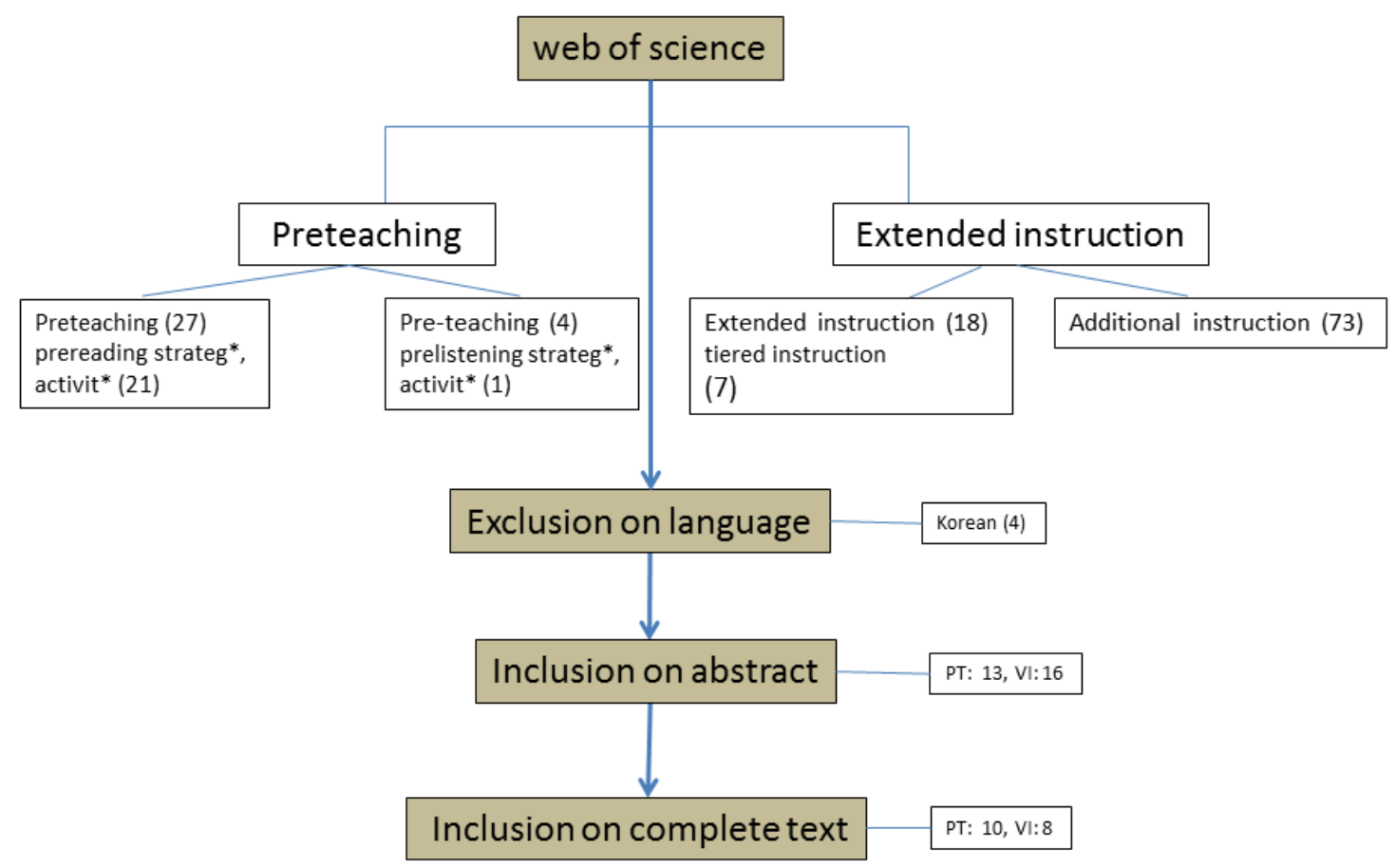

Figure 2. Search strategy.

\subsection{Search Terms}

Search items were used in several phases in the Web of Science-database. Initially, a limited set of search items was used. Studies on preteaching were sought with the queries 'preteaching' and 'pre-teaching'. 'Extended instruction' and 'additional instruction' were used to search for studies on the second instructional strategy. Truncation was used to find similar items. After initial reading of abstracts, a selection of several additional search items was added. For preteaching, these were: 'prereading strategy ${ }^{* \prime}$, 'prereading activit ${ }^{* \prime}$, 'prelistening strategy ${ }^{* \prime}$ and 'prelistening activit ${ }^{* \prime}$. For extended instruction, an additional query was made with 'tiered instruction'. No relevant studies were retained with 'complex instruction', 'small group instruction', 'prewriting activit"' or 'prewriting strategy *'.

\section{Criteria for Inclusion or Exclusion}

As shown in Figure 2, initially many of studies were regarded as potentially relevant. After the selection of abstracts, a list of ten studies for preteaching and eight studies for extended instruction was made based on full texts. The large reduction of papers is to be understood by the fact that the used search items are equally in use in other contexts. Preteaching is often used as an adverb (e.g., pre-teaching interview, pre-teaching score), which is evidently not applicable. Extended instruction and additional instruction generated many studies in computer sciences, which are also beyond the scope of this work. Several studies were also excluded based on language. They were written in Korean on preteaching and pre-teaching [40-43]. Since the research questions focus on the matter of differences within one class, studies that offered additional instruction out of the classroom (for instance by a special needs teacher) were not included. Neither were studies on segregated special needs education.

In order to respond to the research questions, the following two criteria for inclusion were used: (1) the study discusses findings on preteaching or extended instruction such as presented in the introductory section; and/or (2), the instructional strategy can be used to respond to differences in instructional needs in a general educational context. Both quantitative and qualitative studies with different research designs (such as randomized control trials, multiple baseline trials and case studies) were included. No criterion for age was used. As a result, the age range of target groups varies from primary to tertiary education. 


\subsection{Extraction and Synthesis of Findings}

Cooke, Smith, and Booth suggest using the SPIDER-tool for analysis of studies with qualitative elements [44]. It presents the essential data of the selected studies. In particular, the following elements are analyzed: Sample (S), Phenomenon of Interest (PI), Design (D), Evaluation (E), and Research type (R). Tables 2 and 5 summarize the spider-analysis that served as a vantage point for further analysis. This process of analysis was conducted by the first author in an iterative process of taking notes combined with categorizing the papers. Principles of thematic analysis were adopted to synthesize the data. Both research questions initially served as a basic coding structure. Findings were categorized in codes and eventually organized in descriptive themes using the constant comparative method [45]. After refinement, the results were discussed in detail with the second and third authors in order to further refine the quality of the findings. The result of this process is summarized in Tables 1 and 4, and is described in more detail in the results section.

\subsection{Drawing Conclusions}

The complexity of the praxis of educational sciences often does not permit the drawing of simple conclusions [46]. This review of literature aimed to unravel the complexity of teaching in a differentiated classroom by drawing conclusions from existing research. In doing so, we aimed to foster teachers' professional decision-making. Both research questions are addressed separately in the findings section. A synthesis of what was found in the literature on each question has been added at the end of each subsection of the findings. Subsequently, the discussion section revisits the findings based on the literature on the matter of catering for different instructional needs.

\section{Findings}

In this section, both research questions are addressed separately for preteaching and extended instruction. In each section, first it is described how PT or EI may be used as a differentiated instruction strategy, second differentiated effects of PT and EI are described. At the end of each section, a brief summary of findings is presented.

\subsection{Preteaching}

Table 1 provides an overview of the selection of papers on preteaching. Studies in Column C use a differentiated teaching perspective in their research design. Other studies (D and E) address an undifferentiated perspective on preteaching that is used in a whole-group approach. Studies in Column $\mathrm{D}$ describe different effects within one group. Except for two studies, all papers focus on language education to prepare students for a specific activity. Vocabulary preteaching advance organizers are used. Vocabulary preteaching is foremost used in primary education. Advance organizers are more often used in secondary or tertiary education.

Table 1. Research interest studies on preteaching.

\begin{tabular}{|c|c|c|c|c|c|}
\hline & A & B & $\mathrm{C}$ & D & E \\
\hline & Focus & $\begin{array}{l}\text { Preparatory intervention: } \\
\text { Vocabulary preteaching (VP) } \\
\text { Advanced organizer (AO) }\end{array}$ & $\begin{array}{l}\text { Differentiated } \\
\text { design }\end{array}$ & $\begin{array}{l}\text { Differential } \\
\text { effects }\end{array}$ & $\begin{array}{c}\text { Undifferentiated } \\
\text { design, no } \\
\text { differential effects }\end{array}$ \\
\hline Beck et al., 2009 & Reading skills & VP & $x$ & & \\
\hline Burns et al., 2004 & Reading skills & VP & $x$ & & \\
\hline Coulter \& Lambert, 2015 & Reading skills & VP & $x$ & & \\
\hline Chung, 2002 [47] & Listening skills & $\mathrm{VP}, \mathrm{AO}$ & & $x$ & \\
\hline Denner et al., 2003 & Reading skills & $\mathrm{AO}$ & & $x$ & \\
\hline Elkhafaifi, 2005 [48] & Listening skills & $\mathrm{AO}$ & & & $x$ \\
\hline Jafari \& Hashim, 2012 & Listening skills & $\mathrm{VP}, \mathrm{AO}$ & $x$ & $x$ & \\
\hline Lawless et al., 2007 & Browsing the Internet & $\mathrm{AO}$ & & & $x$ \\
\hline Munk et al., 2010 & Scientific concepts & VP & $x$ & & \\
\hline Osa-Melero, 2012 [49] & Reading skills & $\mathrm{AO}$ & & $x$ & \\
\hline
\end{tabular}




\subsubsection{The Use of Preteaching as a Differentiated Instructional Strategy}

Those studies that use preteaching for vocabulary instruction do so for a particular target group. Table 2 provides an overview of the target groups. This could be a limited number of students with a particular special educational need. It could also be a larger group of students with a lower readiness level. In none of the studies, explicit references to students' instructional needs were found. Hence, the supposed instructional need is based on a one-dimensional category. A difference can be made between studies based on a fixed category such as a learning disorder and studies that do not regard the instructional needs as being a fixed category [50-52]. In this case, preteaching is used to monitor the learning progress of a specific target group. Jafari and Hashim use the learning outcomes of a complete group, but instruction is tailored based on assessment results [53]. Those students performing one standard deviation higher or lower than their peers are distinguished. Munk, Gibb, and Caldarella adopt a more flexible perspective on instructional needs; they use formative assessment to determine students' instructional needs. Their category of 'students at risk' consists of students with a learning disorder, but also other students at risk of academic failure [54].

Four studies on vocabulary use multiprobe baseline designs [50-52,54]. In each of these cases, focus rests on a limited number of students that receive a differentiated program based on a particular student characteristic such as reading difficulties or behavioral disorder. This particular focus means that no data are provided on other students in the class. Munk, Gibb and Caldarella mention a significant increase in student satisfaction for those students with an at-risk profile receiving preteaching [54]. Given the costly structure of the program, the authors recommend limiting it to those students with an at-risk profile.

Several types of advance organizers are used in the selected studies. Table 3 provides an overview of them. Listening, reading and writing options are described. Although the extent to which teachers actively engage in this sort of preteaching varies, each of these advance organizers intends to activate pre-existing knowledge, or to pre-structure students' thoughts. 
Table 2. SPIDER-analysis of studies on preteaching.

\begin{tabular}{|c|c|c|c|c|c|c|c|}
\hline & \multicolumn{2}{|c|}{ Sample } & \multicolumn{2}{|c|}{ Phenomenon of Interest } & \multirow[t]{2}{*}{ Design } & \multirow[t]{2}{*}{ Evaluation } & \multirow{2}{*}{$\begin{array}{r}\text { Research Type } \\
\text { Quantitive }(\mathrm{Qt}), \\
\text { qualitative }(\mathrm{Ql}) \text { or } \\
\text { mixed method }(\mathrm{Mm})\end{array}$} \\
\hline Study & Level & $\begin{array}{l}\text { Number of } \\
\text { participants, target } \\
\text { group }\end{array}$ & $\begin{array}{l}\text { Dependent } \\
\text { variable }\end{array}$ & $\begin{array}{l}\text { Independent } \\
\text { variable }\end{array}$ & & & \\
\hline Burns et al. (2004) & Primary & $\begin{array}{l}\text { 42, behavioral } \\
\text { disorder }\end{array}$ & $\begin{array}{l}\text { Individual PT, } \\
\text { keywords }\end{array}$ & $\begin{array}{l}\text { Reading skills: } \\
\text { number } \\
\text { words/minute }\end{array}$ & $\begin{array}{l}\text { multiprobe } \\
\text { baseline } \\
\text { experimental }\end{array}$ & Increased reading proficiency: 8 words/minute & Qt \\
\hline Beck et al. (2009) & Primary & $\begin{array}{l}\text { 2, reading disorder, } \\
\text { pre-assessment }\end{array}$ & $\begin{array}{l}\text { Individual PT, } \\
\text { words and } \\
\text { phonology }\end{array}$ & $\begin{array}{l}\text { Reading fluency } \\
\text { and } \\
\text { comprehension }\end{array}$ & $\begin{array}{l}\text { single subject } \\
\text { multi-element, } \\
\text { Experimental }\end{array}$ & Significant increase in word comprehension & Qt \\
\hline $\begin{array}{l}\text { Coulter and } \\
\text { Lambert (2015) }\end{array}$ & Primary & $\begin{array}{l}\text { 3, reading disorder, } \\
\text { pre-assessment }\end{array}$ & PT keyword & $\begin{array}{l}\text { Reading skills: } \\
\text { number words, } \\
\text { sentences/time }\end{array}$ & Multiple baseline & Increased fluency and 'accuracy & Qt \\
\hline Chung (2002) & Tertiary & 188 , random & $\begin{array}{l}\text { Vocabulary PT } \\
\text { versus question } \\
\text { previewing }\end{array}$ & $\begin{array}{l}\text { English listening } \\
\text { skills }\end{array}$ & $\begin{array}{l}\text { Experimental, } \\
\text { multimeasure } \\
\text { (ANOVA) }\end{array}$ & $\begin{array}{l}\text { Higher results for question previewing compared to } \\
\text { vocabulary PT. } \\
\text { Result dependent on achievement level of student }\end{array}$ & Qt \\
\hline $\begin{array}{l}\text { Denner, Rickards, } \\
\text { and Albanese } \\
\text { (2003) }\end{array}$ & Secondary & 74, random & $\begin{array}{l}\text { Story Impressions } \\
\text { preview versus } \\
\text { Content Preview }\end{array}$ & $\begin{array}{l}\text { Factual knowledge } \\
\text { history text }\end{array}$ & $\begin{array}{l}\text { Experimental, } \\
\text { comparative, } \\
\text { (MANOVA) }\end{array}$ & $\begin{array}{l}\text { SI: increased content recall. } \\
\text { CP: no significant change in results }\end{array}$ & Qt \\
\hline Elkhafaifi (2005) & Tertiary & 111 & $\begin{array}{l}\text { Vocabulary } \\
\text { Preview versus } \\
\text { q-Question } \\
\text { Previewing }\end{array}$ & $\begin{array}{l}\text { Listening skills, } \\
\text { Arabic based on } \\
\quad \text { video }\end{array}$ & $\begin{array}{l}\text { Experimental, } \\
\text { comparative } \\
\text { (MANOVA) }\end{array}$ & $\begin{array}{l}\text { QP highest effectivity regarding distracter activity } \\
\text { and VP }\end{array}$ & Qt \\
\hline $\begin{array}{l}\text { Jafari and Hashim } \\
\text { (2012) }\end{array}$ & Tertiary & $\begin{array}{c}175, \\
\text { pre-assessment, } \\
1 \text { standard } \\
\text { deviation above or } \\
\text { below } \\
\end{array}$ & $\begin{array}{l}\text { Key sentences } \\
\text { previewing and } \\
\text { Vocabulary PT } \\
\text { versus control } \\
\quad \text { group }\end{array}$ & $\begin{array}{l}\text { Listening skills, } \\
\text { English 2nd } \\
\text { language }\end{array}$ & $\begin{array}{l}\text { Experimental, } \\
\text { comparative } \\
\text { (ANCOVA) + } \\
\text { interviews } \\
\text { students }\end{array}$ & $\begin{array}{l}\text { All students benefit from intervention, regardless of } \\
\text { achievement level: identification core concepts of } \\
\text { text. Stronger motivation and self-confidence; } \\
\text { reduction stress and anxiety. No consensus on } \\
\text { added value among participants }\end{array}$ & $\mathrm{Mm}$ \\
\hline Osa-Melero (2012) & Tertiary & 46, random & $\begin{array}{l}\text { Cooperative PT } \\
\text { versus individual } \\
\text { prereading }\end{array}$ & $\begin{array}{l}\text { Listening skills, } \\
\text { Spanish }\end{array}$ & $\begin{array}{l}\text { Experimental, } \\
\text { comparative } \\
\text { (MANOVA) }\end{array}$ & Differential effects dependent on assessment type & Qt \\
\hline $\begin{array}{l}\text { Lawless, Schrader, } \\
\text { and Mayall (2007) }\end{array}$ & Tertiary & 42 , random & Prereading activity & $\begin{array}{c}\text { Online } \\
\text { information query }\end{array}$ & $\begin{array}{l}\text { Experimental } \\
\text { (ANCOVA) }\end{array}$ & $\begin{array}{l}\text { Significant increase in knowledge; Higher } \\
\text { performance in addressing complex tasks }\end{array}$ & Qt \\
\hline Munk et al. (2010) & Secondary & $\begin{array}{l}\text { 3, pre-assessment + } \\
\text { ongoing } \\
\text { assessment } \\
\text { students at risk }\end{array}$ & $\begin{array}{c}\text { Collaborative PT } \\
\text { versus individual } \\
\text { textbook } \\
\text { instruction }\end{array}$ & Biology concepts & $\begin{array}{l}\text { Case-study, } \\
\text { multiprobe } \\
\text { baseline }\end{array}$ & $\begin{array}{l}\text { Increased performance on test. Self-declared } \\
\text { increase in confidence }\end{array}$ & $\mathrm{Mm}$ \\
\hline
\end{tabular}


Table 3. The use of advance organizers as preteaching.

\begin{tabular}{ccc}
\hline Activity & Reference & Students ... \\
\hline Individual prereading activity & Osa-Melero (2012) & receive instruction with help from textbook \\
\hline Questions preview & Chung (2002); Elkhafaifi (2005) & $\begin{array}{c}\text { read indicative questions on a text before } \\
\text { reading the actual text }\end{array}$ \\
\hline Vocabulary preview & Elkhafaifi (2005) & $\begin{array}{c}\text { read difficult vocabulary of a text before } \\
\text { reading a text in which they feature }\end{array}$ \\
\hline Key sentences & Jafari \& Hashim (2012) & $\begin{array}{c}\text { read the most important sentences of a text } \\
\text { before reading the actual text }\end{array}$ \\
\hline Content preview & $\begin{array}{c}\text { Denner et al. (2003); } \\
\text { Lawless et al. (2007) }\end{array}$ & $\begin{array}{c}\text { read a short summary of core concepts of a } \\
\text { text before reading the actual text }\end{array}$ \\
\hline (Written) story impressions & Denner (2003) & $\begin{array}{c}\text { are asked to compose the (possible) end of a } \\
\text { story and write this down }\end{array}$ \\
\hline
\end{tabular}

\subsubsection{Differential Effects of Preteaching}

All studies report on learning effects. The large diversity of target groups, interventions and modes of measurement make it impossible to compare them. Based on the different forms of preteaching, namely vocabulary instruction and advance organizers, the first seems to have been mostly studied in primary education, and the second used to measure learning effects in secondary education.

Jafari and Hashim compare a group of students who receive vocabulary preteaching with a group that receives an advance organizer in preparation for reading skills [53]. It is the only study that not only measures the effectiveness of learning, but also systematically gathers data on the experiences of participants based on interviews. Participants of this study report increased motivation and self-confidence, and decreased feelings of anxiety because of the preteaching activities. No explanation is given for the different effectiveness of both strategies. However, different perceptions about the added value of the intervention between the participants are stressed. Whereas some students appreciated the intervention, others did not find it very useful. This could refer to students' self-perceived instructional needs.

Only Denner, Rickards and Albanese report on the time students spend on their task [55]. This can be seen as one of the factors that determine learning effects. In this study, a part of the explanation for differences in learning effectiveness ('story impressions' versus 'content preview') is related to the differences in time spent on tasks. In other studies, no elaborations are made on this aspect. Nor do other studies consider the cost of interventions, which are closely tied to the aspect of time spent on tasks.

What do we learn about the use of preteaching to cater for students with different instructional needs?

Analysis of the selected studies reveals the complexity of the decisions teachers must make when catering for different instructional needs. The literature does not present sufficient answers to fully deconstruct this complexity. Research designs on preteaching always adopt a significant reduction of the complexity of teaching in a differentiated class.

The only studies on preteaching that address differences in instructional needs in their research design are those of Jafari and Hashim and Munk et al. [53,54]. Both indicate that tailored instruction could enhance students' listening comprehension or let them gain necessary content information. It occurs that both pre-assessments and formative assessments are vital to assess students' instructional needs. Pre-assessment that is based on fixed student characteristics such as a learning disorder may not be the most concise way to determine whether a (group of) student(s) needs preteaching. Formative assessment reveals more genuine information on students' instructional needs.

Teachers may choose from two types of preteaching activities: vocabulary teaching and advanced organizers. No comprehensive conclusions may be drawn about the learning effectiveness of the selected studies. Several indications were found other than cognitive learning outcomes; affective 
outcomes must also be taken into account when using preteaching to cater for students' different instructional needs.

\subsection{Extended Instruction}

Eight studies were found with a focus on extended instruction. All these proposed supplementary instruction for students based on language elements. All studies focused at primary education, no data exist on the use of the strategy at secondary or tertiary school level. Table 4 provides an overview of the focus of the studies. Five studies focus on vocabulary. Increased vocabulary knowledge is taken as a measure for success of the extended instruction. Three other studies are also related to language components, but they assess reading skills or phonological awareness. In three cases extended instruction was targeted at a limited number of students within a class (small group instruction-SGI) which in the literature is also described as tiered instruction. When extended instruction is studied like this, it is a typical example of catering for students' different instructional needs. In other studies, Rich Vocabulary Instruction (RVI) is used. This means that a strategy is used in which vocabulary instruction is highly contextualized and with several different meanings. It is a time-intensive strategy that aims at deep insight.

Table 4. Research focus of studies on extended instruction.

\begin{tabular}{|c|c|c|c|c|c|}
\hline & $\begin{array}{c}\text { Focus: Word } \\
\text { Knowledge (W) } \\
\text { Reading Skills (R) } \\
\text { Phonological } \\
\text { Awareness (P) }\end{array}$ & $\begin{array}{c}\text { Type: Rich } \\
\text { Vocabulary } \\
\text { Instruction (RVI) } \\
\text { Small Group } \\
\text { Instruction (SGI) }\end{array}$ & $\begin{array}{l}\text { Differentiated } \\
\text { Design }\end{array}$ & $\begin{array}{l}\text { Differential } \\
\text { Effects }\end{array}$ & $\begin{array}{l}\text { Undifferentiated } \\
\text { Design, No } \\
\text { Differential } \\
\text { Effects }\end{array}$ \\
\hline August et al. (2016) & $\mathrm{W}$ & RVI & $x$ & $\mathrm{x}$ & \\
\hline Coyne et al. (2007) & $\mathrm{W}$ & RVI & & $\mathrm{x}$ & \\
\hline Coyne et al. (2009) & W & RVI & & $\mathrm{x}$ & \\
\hline $\begin{array}{l}\text { Heiner, Beck, and } \\
\text { Mostow (2006) [56] }\end{array}$ & $\mathrm{W}$ & RVI & & & $x$ \\
\hline Kruse et al. (2015) & $\mathrm{P}$ & SGI & $x$ & $x$ & \\
\hline $\begin{array}{l}\mathrm{O}^{\prime} \text { Connor, Harty, and } \\
\text { Fulmer (2005) }\end{array}$ & $\mathrm{R}$ & SGI & $x$ & $x$ & \\
\hline Schuele et al. (2008) & $\mathrm{P}$ & SGI & $\mathrm{x}$ & $x$ & \\
\hline Vadasy et al. (2015) & $\mathrm{W}$ & RVI & & & $x$ \\
\hline
\end{tabular}

\subsubsection{The Use of Extended Instruction as a Differentiated Instructional Strategy}

The instructional needs of students are assessed differently in the selected papers. Table 5 provides the SPIDER-analysis of the studies. A randomized population is studied in four cases. In other cases, pre-assessment is effectuated [57,58]. In addition to this, studies from August et al. and O'Connor et al. use formative assessment to monitor students' learning outcomes, which allows teachers to continuously adapt teaching to the instructional needs of students at risk $[59,60]$.

Studies with a focus on tiered instruction are strongly divergent in research design. Schuele et al. focus on a relatively large group of students that receive supplementary instruction in language skills [58]. Kruse, Spencer, Olszewski, and Goldstein focus on elements of phonological awareness. With a multiple baseline design, the progress of a limited number of at risk students, who receive extended instruction in small groups, is monitored [57]. The study with the largest scope is that of August et al. [60]. They monitor the learning of a group of 509 students at risk of academic failure using formative assessment. Their intervention focuses on vocabulary instruction in primary education. This study is comparable with that of $\mathrm{O}^{\prime}$ Connor et al., who focus on the monitoring of reading skills using SGI [59]. 
Table 5. Spider-analysis of studies on extended instruction.

\begin{tabular}{|c|c|c|c|c|c|c|c|}
\hline \multirow[b]{2}{*}{ Study } & \multicolumn{2}{|c|}{ Sample } & \multicolumn{2}{|c|}{ Phenomenon of interest } & \multirow[t]{2}{*}{ Design } & \multirow[t]{2}{*}{ Evaluation } & \multirow{2}{*}{$\begin{array}{c}\text { Research } \\
\text { Type }\end{array}$} \\
\hline & Level & $\begin{array}{c}\text { Number of } \\
\text { Participants, target }\end{array}$ & $\begin{array}{l}\text { Dependent } \\
\text { variable }\end{array}$ & Independent variable & & & \\
\hline $\begin{array}{l}\text { Vadasy, Sanders, } \\
\text { and Herrera (2015) }\end{array}$ & Primary & 1232 , random & $\begin{array}{l}\text { Vocabulary and } \\
\text { reading } \\
\text { comprehension }\end{array}$ & $\begin{array}{l}\text { RVI, tier } 2 \text { words } \\
\quad(n=280)\end{array}$ & $\begin{array}{l}\text { Multilevel } \\
\text { hierarchic } \\
\text { modelling }\end{array}$ & $\begin{array}{l}\text { Higher performance on vocabulary } \\
\text { comprehension Discussion about time } \\
\text { intensivity }\end{array}$ & Qt \\
\hline Kruse et al. (2015) & Primary & 7, pre-assessment & $\begin{array}{l}\text { Phonological } \\
\text { awareness }\end{array}$ & SGI (tier 2) & $\begin{array}{l}\text { Multiple baseline: } \\
\text { progress } \\
\text { monitoring }\end{array}$ & $\begin{array}{l}\text { Differential effects dependent on target public } \\
\text { Suggestion for tier } 1 \text { or } 3 \text { activities } \\
\text { Reference to student emotional wellbeing }\end{array}$ & Qt \\
\hline $\begin{array}{l}\text { Coyne, McCoach, } \\
\text { and Kapp (2007) }\end{array}$ & Primary & 32 , random & Word knowledge & $\begin{array}{l}\text { RVI versus embedded } \\
\text { word instruction }\end{array}$ & $\begin{array}{l}\text { Experimental } \\
\text { comparative, } \\
\text { ANOVA }\end{array}$ & $\begin{array}{l}\text { Differential effects strategies: extended higher } \\
\text { than embedded }\end{array}$ & Qt \\
\hline $\begin{array}{l}\text { Coyne, McCoach, } \\
\text { Loftus, Zipoli, and } \\
\text { Kapp (2009) }\end{array}$ & Primary & 42 , random & Word knowledge & RVI & $\begin{array}{l}\text { Experimental, } \\
\text { multimeasure } \\
\text { MANOVA }\end{array}$ & $\begin{array}{l}\text { Higher reading comprehension } \\
\text { Extended instruction produces deeper learning } \\
\text { of limited amount of words }\end{array}$ & Qt \\
\hline $\begin{array}{l}\text { Heiner, Beck, and } \\
\text { Mostow (2006) }\end{array}$ & Primary & 14 , random & Word knowledge & $\begin{array}{l}\text { Human instruction } \\
\text { versus 'no instruction' } \\
\text { and embedded word } \\
\text { instruction }\end{array}$ & Logistic regression & Significant difference. Data unspecified & Qt \\
\hline $\begin{array}{l}\text { O'Connor et al. } \\
\text { (2005) }\end{array}$ & Primary & $\begin{array}{l}\text { 200, ongoing } \\
\text { formative assessment }\end{array}$ & $\begin{array}{l}\text { Reading skills and } \\
\text { comprehension }\end{array}$ & $\begin{array}{l}\text { SGI for students } \\
\text { non-responsive for tier } \\
1 \text { instruction }\end{array}$ & $\begin{array}{l}\text { Experimental, } \\
\text { multimeasure }\end{array}$ & $\begin{array}{l}\text { Short term: higher results for reading skills and } \\
\text { comprehension } \\
\text { Long term: decreased number of special needs } \\
\text { education }\end{array}$ & Qt \\
\hline $\begin{array}{l}\text { August et al. } \\
\quad(2016)\end{array}$ & Primary & $\begin{array}{l}509 \text { students at risk; } \\
\text { ongoing assessment }\end{array}$ & $\begin{array}{l}\text { (Academic) word } \\
\text { knowledge }\end{array}$ & $\begin{array}{l}\text { RVI versus embedded } \\
\text { instruction and } \\
\text { 'reinforcer activity' }\end{array}$ & $\begin{array}{l}\text { Comparative } \\
\text { experimental } \\
\text { (ANOVA) }\end{array}$ & $\begin{array}{l}\text { Increased word comprehension for both } \\
\text { strategies: larger for extended than embedded. } \\
\text { No effect of reinforcer activity }\end{array}$ & Qt \\
\hline $\begin{array}{l}\text { Schuele et al. } \\
\text { (2008) }\end{array}$ & Primary & $\begin{array}{l}113 \text { pre-assessment } \\
\text { students at risk }\end{array}$ & $\begin{array}{l}\text { Phonological } \\
\text { awareness (control } \\
\text { group: regular } \\
\text { programme) }\end{array}$ & $\begin{array}{l}\text { Small-group Tiered } \\
\quad \text { instruction }\end{array}$ & $\begin{array}{l}\text { Experimental, } \\
\text { (ANOVA) }\end{array}$ & $\begin{array}{l}\text { Significant increase in literacy on } 3 \text { parameters. } \\
\text { In particular for low-achievers }\end{array}$ & Qt \\
\hline
\end{tabular}


Schuele et al. notice factors complicating the implementation of the strategy they adopted [58]. They indicate that the application of extended instruction is more difficult for older students than for younger ones, as it becomes increasingly difficult to compose relevant tasks for the students at risk while combining this with appropriate tasks for the other students in class. No attention was dedicated in these studies to students with more limited instructional needs. This means that as a result of the focus on students at risk, the perspective of other students in the class is out of sight. Kruse et al. point to practical difficulties such as the limitations in staff availability and to time constraints [57].

\subsubsection{Differential Effects of Extended Instruction}

Several comparative studies note that comparable measures generate different results depending on the assessment method used [61,62]. In addition to this, the time-intensiveness of a measure appears to be a relevant factor that mediates the effectiveness of a measure [62,63]. Most other studies do not elaborate on these aspects in their analysis.

O'Connor, Harty, and Fulmer present an important study where students received extended instruction based on formative assessment [59]. This 'tier $2^{\prime}$ intervention was dependent on students' progress, and therefore varied between eight weeks and two years. They indicate that they cannot assess how much or how quickly students would have progressed without the intervention. However, compared with historical data, the students who did receive extended instruction were less likely to be directed to special needs education. This finding indicates that extended instruction based on formative assessment assures a better catering for students' instructional needs.

Several studies are selected using Rich vocabulary instruction (RVI) as a strategy (see Table 4). According to these studies, this yields positive results. The studies of Coyne et al., and August et al. make an analysis of the variance of an intervention with extended instruction compared with embedded instruction [60-62]. This latter one is an alternative in which vocabulary is taught with word meanings written embedded in the proposed texts. This approach is more superficial than RVI. Notwithstanding this, a larger number of words can be treated as a result of the superficial structure of the approach. Comparative studies point to a larger learning effectiveness of extended instruction compared with embedded instruction. Still, Coyne et al. conclude that different modes of application exist depending on the desired learning targets [62]. In particular, extended instruction is reported to be more useful when deep vocabulary knowledge is needed, and embedded instruction would be more appropriate for more superficial targets.

3.2.3. What Do We Learn about the Use of Extended Instruction to Cater for Students with Different Instructional Needs?

In order to understand the use of extended instruction in a context of different instructional needs, several points need to be addressed. In two of the four cases, the instructional needs of students are assessed dynamically using formative assessment. Even in these studies, no data were provided for students other than those at risk; in particular, the instructional needs of talented students remain out of scope. When extended instruction is provided, this can be done in various ways: both content and structure may vary. Students with high instructional needs may receive RVI (enriched content and context), or they may receive Small group instruction (SGI—structure, scaffolding, feedback).

Several authors refer to the learning effectiveness of the interventions they have undertaken. However, the empirical basis for these statements is too limited to draw generic conclusions about extended instruction. In particular, it is not clear how the effectiveness of a strategy relates to time invested (students' time on task, time spent by teachers), and thus how it relates to the cost of an intervention. Moreover, also regarding the aimed targets, divergence was noticed. Depending on which aim a teacher has (e.g., deep contextual knowledge of a few words versus superficial knowledge of a large number), different strategies may be preferred. 


\section{Discussion}

The selected studies help us to better understand how complex differentiated instruction is. This complexity is not reflected in the research design of the studies found. Still, analysis of studies with a focus on preteaching or extended instruction provides insight in the role these strategies can play in providing tailored instruction that caters for different instructional needs. Overall, it is noticed that most of the studies under consideration were carried out in language education settings. Moreover studies on extended instruction were exclusively carried out in primary education. In consequence, the following conclusions are directly beneficial to those who are working in this field. The potential for wider application is large, as studies in different domains such as science education or online skills indicate $[54,64]$.

\subsection{How Can Preteaching and Extended Instruction Be Used as a Strategy of Differentiated Instruction?}

Tomlinson and Hall suggest basing differentiated instruction on student pre-assessment [12,13]. Not only are readiness levels assessed, but also other student characteristics are relevant. Drawing upon their ideas on differentiated instruction, it may be claimed that the instructional needs of students have characteristics other than purely cognitive ones. However, studies under review mainly focus on readiness level, or on assumptions on students' instructional needs. Implicitly, it is often assumed that students with an at-risk profile (e.g., lower performing than peers, learning disorders) have an increased instructional need. As a result of this, it is not always clear to what extent these characteristics align with the actual instructional needs of students. In addition to this, it is even less clear what the instructional needs of other students in a group would be. Students in a multicultural context might face being typecast when the application of these strategies is based upon single-issue characterization $[65,66]$. Several studies use fixed student characteristics to base their measures on. In particular, a direct link is made between a learning disorder and a behavioral disorder. However, literature on differentiated instruction suggest a reticence with differentiation based on fixed student characteristics $[67,68]$. Smets argues that high-quality differentiated instruction is fostered by a more detailed assessment of students' instructional needs instead of one-dimensional stereotyping [69]. This is why the use of ongoing formative assessment may be appropriate to assess students' instructional needs [17,70]. The few studies that engage with formative assessment in their data collection are consequently more aligned with such practice $[59,70]$. Figure 3 presents the difference between studies with or without formative assessment.

Linear perspective

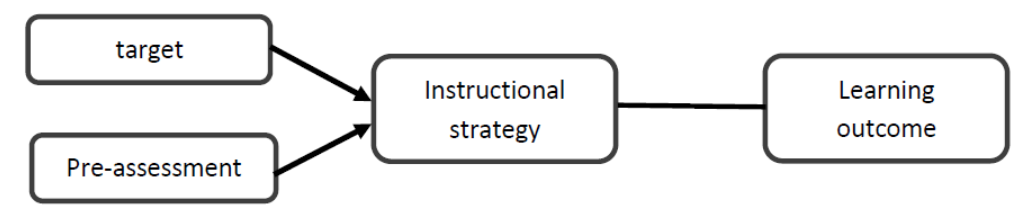

Cyclical perspective

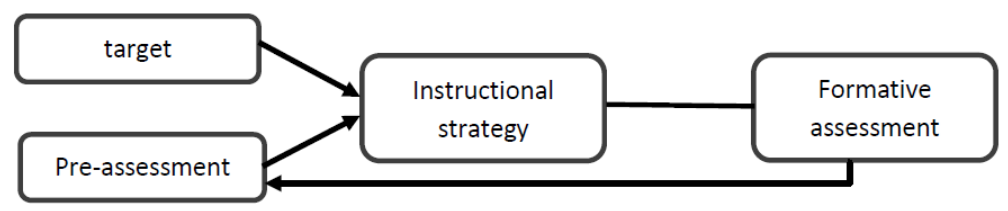

Figure 3. Linear or cyclical perspective on instructional design and data collection.

It is striking that the perspective of high performing students usually remains beyond the scope of these studies. Where preteaching or extended instruction are used to provide tailored instruction for a 
group of students with a particular profile, no attention is paid to the interests of other students such as high performers. This finding contrasts with recommendations to also provide tailored instruction for gifted students [71,72]. As a result of this, it is unclear to what extent preteaching and extended instruction may eventually also be used to develop learning processes that aim at excellence for all students [73]. Providing additional tailored instruction in the form of preteaching or extended instruction may create opportunities for the most talented students in multicultural environments, either to excel or to further develop their talents, without decreasing educational opportunities for other students in a group [74]. We conclude that the studies under focus use research designs that encompass a reduction of the complexity of teaching in a differentiated class. To omit the perspective of the most talented learners in a group risks neglecting important chances to foster equitable education for all.

Other factors to be considered when catering for students with different instructional needs are as follows: the type of instruction may vary (vocabulary instruction, advanced organizers), the chosen content must be considered (listening, reading, writing), and the aimed target (superficial versus deep knowledge) may determine the type of instruction provided for. Hence, teachers who want to cater for the different instructional needs in their heterogeneous classes must take into account this variety of factors mediating the implementation of preteaching and extended instruction, all of which may influence teachers' agency in complex heterogeneous settings [75,76].

\subsection{Which Differential Effects of Preteaching and Extended Instruction Have Been Described?}

Effects on learning results are the most often referred to in the studies found. In both differentiated and undifferentiated designs, several positive learning effects are to be found. Given the large qualitative differences between these studies, no generic answers to questions on learning effects may be given. Moreover, given the complexity of differentiated teaching, it may be questioned whether the idea of generic statements about the teaching strategies under consideration can be obtained [77]. The large number of contextual factors, which are described above, make this a highly ambitious endeavor. In this study, references to both cognitive and affective effects of preteaching and extended instruction were found. Several studies refer to an increase of learning for a target group of students with specific instructional needs. This is particularly so for specific types of goals related to literacy such as word comprehension (August et al.), reading proficiency (Burns et al.) or phonological awareness $[51,58,70]$. The effects are said to be mediated by contextual factors such as the type of preteaching or extended instruction or observed learning progress and dependent on the targeted learning goals. Also, affective effects such as motivation or self-efficacy are to be taken into account when assessing the use of preteaching and extended instruction [53,57]. As a result of this, evidence-informed teachers' decision-making is crucial to catering for students' different instructional needs [78]

More empirical studies that acknowledge this complexity are needed in order to provide deeper insight in the subject.

\section{Limitations}

No selection between the papers was made upon qualitative criteria. We have attempted to provide insight into the quality of the selected studies by providing maximal transparency about qualitative criteria in all studies. As an initial quality check, only studies in the Web of Science-database were selected. Possibly more practice-oriented studies in other databases would present additional information on how preteaching or extended instruction contribute to catering for the different instructional needs of students.

\section{Conclusions}

This review of literature adds to our understanding of the complexity of teaching for equity in heterogeneous classes. Preteaching and extended instruction are two strategies that present potential for instructional design that intends to cater for students' different instruction needs. 
Thoughtful progress monitoring is needed to do this. Both pre-assessment and formative assessment may be used. The strategies are said to influence learning effects and to foster affective results such as increased self-confidence. Current studies on preteaching and extended instruction predominantly used linear and fixed research designs. To achieve a cyclical perspective on instructional design, ongoing assessment of students' instructional needs is needed to thoughtfully apply preteaching and extended instruction. A series of contextual factors determine the outcomes when using preteaching or extended instruction to cater for students' different instructional needs. Depending on the intended learning target or the availability of time, money or other factors, different strategies may be preferred.

Funding: This research was funded by pracitise-oriented scientific research funding of the Karel de Grote University College.

Conflicts of Interest: The authors declare no conflicts of interest.

\section{References}

1. Stockard, J.; Wood, T.; Coughlin, C.; Khoury, C. The effectiveness of direct instruction curricula: A meta-analysis of a half century of research. Rev. Educ. Res. 2018, 88. [CrossRef]

2. Kapur, M.; Bielaczyc, K. Designing for productive failure. J. Learn. Sci. 2012, 21, 45-83. [CrossRef]

3. Dean, D.; Kuhn, D. Direct instruction vs. discovery: The long view. Sci. Educ. 2007, 91, 384-397. [CrossRef]

4. Klahr, D.; Nigam, M. The equivalence of learning paths in early science instruction-Effects of direct instruction and discovery learning. Psychol. Sci. 2004, 15, 661-667. [CrossRef] [PubMed]

5. Parsons, S.; Vaughn, M.; Scales, R.; Gallagher, M.; Parsons, A.; Davis, S.; Allen, M. Teachers' instructional adaptations: A research synthesis. Rev. Educ. Res. 2017, 88, 205-242. [CrossRef]

6. Schleicher, A.E. Preparing Teachers and Developing School Leaders for the 21st Century. Lessons from around the World; Retrieved from Paris; OECD: Paris, France, 2013.

7. Dochy, F.; Segers, M.; Van den Bossche, P.; Gijbels, D. Effects of problem-based learning: A meta-analysis. Learn. Instr. 2003, 13, 533-568. [CrossRef]

8. Cordova, J.R.; Sinatra, G.M.; Jones, S.H.; Taasoobshirazi, G.; Lombardi, D. Confidence in prior knowledge, self-efficacy, interest and prior knowledge: Influences on conceptual change. Contemp. Educ. Psychol. 2014, 39, 164-174. [CrossRef]

9. Ladson-Billings, G. The Dreamkeepers; Jossey-Bass Publishing: San Francisco, CA, USA, 1994.

10. Piazza, S.V.; Rao, S.; Protacio, M.S. Converging recommendations for culturally responsive literacy practices: Students with learning disabilities, English language Learners, and socioculturally diverse learners. Int. J. Multicult. Educ. 2015, 17, 1-20. [CrossRef]

11. Wallerstedt, C.; Pramling, N. Responsive teaching, informal learning and cultural tools in year nine ensemble practice: A lost opportunity. Instr. Sci. 2016, 4, 379. [CrossRef]

12. Tomlinson, C.A. The Differentiated Classroom: Responding to the Needs of All Learners; Association for Supervision and Curriculum Development: Alexandria, Egypt, 2000.

13. Hall, T.; Strangman, N.; Meyer, A. Differentiated instruction and implications for UDL implementation. In NCAC Effective Classroom Practices Report; CAST: New York, NY, USA, 2006.

14. Craft, K.; Khanderia, A.; Gowda, M. Educational Achievement: Teaching Strategies, Psychological Factors and Economic Impact; Nova Science Publishers, Inc.: Hauppauge, NY, USA, 2013.

15. Geisen, T. Understanding cultural differences as social limits to learning: Migration theory, culture and young migrants. In International Handbook of Migration, Minorities and Education; Bekerman, Z., Geisen, T., Eds.; Springer: Berlin, Germany, 2012.

16. Miskovic, M.; Curcic, S. Beyond inclusion: Reconsidering policies, curriculum, and pedagogy for Roma students. Int. J. Multicult. Educ. 2016, 18, 1-14. [CrossRef]

17. Black, P.; Wiliam, D. Developing the theory of formative assessment. Educ. Assess. Eval. Account. 2009, 21, 5-31. [CrossRef]

18. Oaksford, L.; Jones, L. Differentiated Instruction Abstract; Leon County Schools: Tallahassee, FL, USA, 2001.

19. Tomlinson, C.A. Differentiating Instruction in Mixed-Ability Classrooms, 2nd ed.; Association for Supervision and Curriculum Development: Alexandria, Egypt, 2001. 
20. VanTassel-Baska, J.; Feng, A.X.; Brown, E.; Bracken, B.; Stambaugh, T.; French, H.; Bai, W.Y. A study of differentiated instructional change over 3 years. Gift. Child Q. 2008, 52, 297-312. [CrossRef]

21. Montalvo, R.; Combes, B.H.; Kea, C.D. Perspectives on culturally and linguistically responsive RTI pedagogics through a cultural and linguistic lens. Interdiscip. J. Teach. Learn. 2014, 4, 203-219.

22. Savage, C.; Hindle, R.; Meyer, L.H.; Hynds, A.; Penetito, W.; Sleeter, C.E. Culturally responsive pedagogies in the classroom: Indigenous student experiences across the curriculum. Asia-Pac. J. Teach. Educ. 2011, 39, 183-198. [CrossRef]

23. Bosker, R. De Grenzen van Gedifferentieerd Onderwijs; Groningen, R., Ed.; University of Groningen: Groningen, The Netherlands, 2005.

24. Kirschner, P.A.; Sweller, J.; Clark, R.E. Why minimal guidance during instruction does not work: An analysis of the failure of constructivist, discovery, problem-based, experiential, and inquiry-based teaching. Educ. Psychol. 2006, 41, 75-86. [CrossRef]

25. Ausubel, D.P. Defense of advance organizers-Reply. Rev. Educ. Res. 1978, 48, 251-257. [CrossRef]

26. Mayer, R.E. 20 Years of research on advance organizers-assimilation theory is still the best predictor of results. Instr. Sci. 1979, 8, 133-167. [CrossRef]

27. Wass, R.; Golding, C. Sharpening a tool for teaching: The zone of proximal development. Teach. High. Educ. 2014, 19, 671-684. [CrossRef]

28. Gay, G. Preparing for culturally responsive teaching. J. Teach. Educ. 2002, 53, 106-116. [CrossRef]

29. Ware, F. Warm demander pedagogy-Culturally responsive teaching that supports a culture of achievement for African American students. Urban Educ. 2006, 41, 427-456. [CrossRef]

30. Blayney, P.; Kalyuga, S.; Sweller, J. Using cognitive load theory to tailor instruction to levels of accounting students' expertise. Educ. Technol. Soc. 2015, 18, 199-210.

31. Slavin, R.E. Ability grouping and student achievement in elementary school—A best evidence synthesis. Rev. Educ. Res. 1987, 57, 293-336. [CrossRef]

32. Kulik, J.A.; Kulik, C.L.C. Meta-analytic findings on grouping programs. Gift. Child Q. 1992, 36, 73-77. [CrossRef]

33. Hallam, S.; Ireson, J.; Davies, J. Primary pupils' experiences of different types of grouping in school. Br. Educ. Res. J. 2004, 30, 515-533. [CrossRef]

34. Lou, Y.P.; Abrami, P.C.; Spence, J.C.; Poulsen, C.; Chambers, B.; Apollonia, S. Within-class grouping: A meta-analysis. Rev. Educ. Res. 1996, 66, 423-458. [CrossRef]

35. Saleh, M.; Lazonder, A.W.; De Jong, T. Effects of within-class ability grouping on social interaction, achievement, and motivation. Instr. Sci. 2005, 33, 105-119. [CrossRef]

36. Greenhalgh, T.; Kristjansson, E.; Robinson, V. Realist review to understand the efficacy of school feeding programmes. Br. Med. J. 2007, 335, 858-861. [CrossRef] [PubMed]

37. Pawson, R.; Greenhalgh, T.; Harvey, G.; Walshe, K. Realist review-A new method of systematic review designed for complex policy interventions. J. Health Serv. Res. Policy 2005, 10, 21-34. [CrossRef] [PubMed]

38. Bogler, R.; Somech, A. Influence of teacher empowerment on teachers' organizational commitment, professional commitment and organizational citizenship behavior in schools. Teach. Teach. Educ. 2004, 20, 277-289. [CrossRef]

39. Kelchtermans, G. Learning from 'good examples of practice'. Teach. Teach. Theory Pract. 2015, 21, 361-365. [CrossRef]

40. Chan, H. Pre-Teaching Technical Vocabulary in an Introductory Information Systems Course: An Experiment Involving Non-Native Speakers of English; Information Resources Management Association: Hershey, PA, USA, 2000.

41. Chin, C. Effects of prereading treatments on low level EFL readers' comprehension of expository texts. Engl. Lang. Lit. Teach. 2010, 16, 1-18.

42. Cho, Y. Effects of prereading activities on EFL elementary school students' reading comprehension and attitudes. Prim. Engl. Educ. 2006, 12, 195-221.

43. Park, G.-P. The effects of vocabulary preteaching and providing background knowledge on L2 reading comprehension. Engl. Teach. 2004, 59, 193-216.

44. Cooke, A.; Smith, D.; Booth, A. Beyond PICO: The SPIDER tool for qualitative evidence synthesis. Qual. Health Res. 2012, 22, 1435-1443. [CrossRef] [PubMed]

45. Barnett-Page, E.; Thomas, J. Methods for the synthesis of qualitative research: A critical review. BMC Med. Res. Methodol. 2009, 9, 59. [CrossRef] [PubMed] 
46. Bakker, C.; Montesano Montessori, M. Complexity in Education: From Horror to Passion; Sense: Rotterdam, The Netherlands, 2016.

47. Chung, J.M. The effects of using two advance organizers with video texts for the teaching of listening in English. Foreign Lang. Ann. 2002, 35, 231-241. [CrossRef]

48. Elkhafaifi, $\mathrm{H}$. The effect of prelistening activities on listening comprehension in Arabic learners. Foreign Lang. Ann. 2005, 38, 505-513. [CrossRef]

49. Osa-Melero, L. A comparative analysis of the impact of cooperative versus textbook-based individual prereading activities on the reading comprehension of students of Spanish. Hispania-J. Devot. Teach. Span. Port. 2012, 95, 299-315.

50. Beck, M.; Burns, M.K.; Lau, M. The Effect of preteaching reading skills on the on-task behavior of children identified with behavioral disorders. Behav. Disord. 2009, 34, 91-99. [CrossRef]

51. Burns, M.K.; Dean, V.J.; Foley, S. Preteaching unknown key words with incremental rehearsal to improve reading fluency and comprehension with children identified as reading disabled. J. Sch. Psychol. 2004, 42, 303-314. [CrossRef]

52. Coulter, G.A.; Lambert, M.C. Access to general education curriculum: The effect of preteaching key words upon fluency and accuracy in expository text. Learn. Disabil. Q. 2015, 38, 248-256. [CrossRef]

53. Jafari, K.; Hashim, F. The effects of using advance organizers on improving EFL learners' listening comprehension: A mixed method study. System 2012, 40, 270-281. [CrossRef]

54. Munk, J.H.; Gibb, G.S.; Caldarella, P. Collaborative preteaching of students at risk for academic failure. Interv. Sch. Clin. 2010, 45, 177-185. [CrossRef]

55. Denner, P.R.; Rickards, J.P.; Albanese, A.J. The effect of story impressions preview on learning from narrative text. J. Exp. Educ. 2003, 71, 313-332. [CrossRef]

56. Heiner, C.; Beck, J.; Mostow, J. Automated vocabulary instruction in a reading tutor. In Intelligent Tutoring Systems, Proceedings; Ikeda, M., Ashley, K.D., Chan, T.W., Eds.; Springer: Berlin, Germany, 2006; Volume 4053, pp. 741-743.

57. Kruse, L.G.; Spencer, T.D.; Olszewski, A.; Goldstein, H. Small groups, big gains: Efficacy of a tier 2 phonological awareness intervention with preschoolers with early literacy deficits. Am. J. Speech-Lang. Pathol. 2015, 24, 189-205. [CrossRef] [PubMed]

58. Schuele, C.M.; Justice, L.M.; Cabell, S.Q.; Knighton, K.; Kingery, B.; Lee, M.W. Field-based evaluation of two-tiered instruction for enhancing kindergarten phonological awareness. Early Educ. Dev. 2008, 19, 726-752. [CrossRef]

59. O'Connor, R.E.; Harty, K.R.; Fulmer, D. Tiers of intervention in kindergarten through third grade. J. Learn. Disabil. 2005, 38, 532-538. [CrossRef] [PubMed]

60. August, D.; Artzi, L.; Barr, C. Helping ELLs meet standards in English language arts and science: An intervention focused on academic vocabulary. Read. Writ. Q. 2016, 32, 373-396. [CrossRef]

61. Coyne, M.D.; McCoach, D.B.; Kapp, S. Vocabulary intervention for kindergarten students: Comparing extended instruction to embedded instruction and incidental exposure. Learn. Disabil. Q. 2007, 30, 74-88. [CrossRef]

62. Coyne, M.D.; McCoach, D.B.; Loftus, S.; Zipoli, R., Jr. Kapp, S. Direct vocabulary instruction in kindergarten: Teaching for breadth versus depth. Elem. Sch. J. 2009, 110, 1-18. [CrossRef]

63. Vadasy, P.F.; Sanders, E.A.; Herrera, B.L. Efficacy of rich vocabulary instruction in fourth- and fifth-grade classrooms. J. Res. Educ. Eff. 2015, 8, 325-365. [CrossRef]

64. Lawless, K.A.; Schrader, P.G.; Mayall, H.J. Acquisition of information online: Knowledge, navigation and learning outcomes. J. Lit. Res. 2007, 39, 289-306.

65. Steel, C.; Aronson, J. Stereotype threat and the intellectual test performance of African Americans. J. Personal. Soc. Psychol. 1995, 69, 797-811. [CrossRef]

66. Villenas, S.; Deyhle, D. Critical race theory and ethnographies challenging the stereotypes: Latino families, schooling, resilience and resistance. Curric. Inq. 1999, 29, 413-445. [CrossRef]

67. Denessen, E.; Douglas, S.A. Teacher expectations and within-classroom differentiation. In International Handbook of Social Psychology of the Classroom; Rubie-Davies, C.M., Stephens, J.M., Watson, P., Eds.; Routledge: London, UK, 2015.

68. Rubie-Davies, C.M.; Stephens, J.M.; Watson, P. International Handbook of Social Psychology of the Classroom; Routledge: London, UK, 2015. 
69. Smets, W. High quality differentiated instruction-A checklist for teacher professional development on handling differences in the general education classroom. Univ. J. Educ. Res. 2017, 5, 2074-2080. [CrossRef]

70. Andrade, H.; Cizek, G. Handbook of Formative Assessment; Routledge: New York, NY, USA, 2010.

71. Kennedy, D.M. Glimpses of a highly gifted child in a heterogeneous classroom. Roep. Rev. 2002, 24, 120-124. [CrossRef]

72. VanTassel-Baska, J. Differentiation in action: The integrated curriculum model. Rev. Educ. 2015, 368, $232-254$. [CrossRef]

73. Tomlinson, C.A. Teaching for excellence in academically diverse classrooms. Society 2015, 52, $203-209$. [CrossRef]

74. Tomlinson, C.A. Complex instruction: A model for reaching up-And out. Gift. Child Today 2017, 41, 7-12. [CrossRef]

75. Priestley, M.; Edwards, R.; Priestley, A.; Miller, K. Teacher agency in curriculum making: Agents of change and spaces for manoeuvre. Curric. Inq. 2012, 42, 191-214. [CrossRef]

76. Sloan, K. Teacher identity and agency in school worlds: Beyond the all-good/all-bad discourse on accountability-explicit curriculum policies. Curric. Inq. 2006, 36, 119-152. [CrossRef]

77. Snyder, S. The Simple, the Complicated, and the Complex: Educational Reform through the Lens of Complexity Theory; OECD: Paris, France, 2013; Available online: http:/ / www.oecd.org/education/ceri/WP_The\%20Simple, \%20Complicated,\%20and\%20the\%20Complex.pdf (accessed on 20 June 2018).

78. Nelson, J.; Campbell, C. Evidence-informed practice in education: Meanings and applications. Educ. Res. 2017, 59, 127-135. [CrossRef]

(c) 2018 by the authors. Licensee MDPI, Basel, Switzerland. This article is an open access article distributed under the terms and conditions of the Creative Commons Attribution (CC BY) license (http:/ / creativecommons.org/licenses/by/4.0/). 